\title{
EFFECT OF MOISTURE CONTENT VARIATION OVER KINETIC REACTION RATE DURING VERMICOMPOSTING PROCESS
}

\author{
J. PALSANIA $^{1 *}-$ R. SHARMA ${ }^{2}-$ J.K.SRIVASTAVA ${ }^{3}-$ D. SHARMA ${ }^{4}$ \\ ${ }^{l} *$ Reader in Civil Engineering, Department of Civil Engineering, Ujjain Engineering College, \\ Ujjian, M.P. India PIN-465010 \\ 2. H.O.D., Department of Civil Engineering, G.T. Polytechnic College, Joara, M.P. India \\ 3. H.O.D., Department of Chemical Engineering, Ujjain Engineering College, Ujjian, \\ M.P.INDIA PIN-465010 \\ ${ }^{4}$ H.O.D., Department of Microbiology, Lok Manya Tilak College, Ujjjain, M.P. India
}

(phone 91-734-2556209, 91-734-2525680, mob. 091-93022-37574)

*Corresponding author

e-mail:palsania_j@yahoo.co.in

(Received $28^{\text {th }}$ March 2007 ; accepted $12^{\text {nd }}$ April 2008)

\begin{abstract}
Even though vermicomposting is an age old process, due to rapid changes in technology in present scenario it is essential to change such process with application of advanced technique available. The same attempt is made by authors during series of their experiments of bioconversion over solid waste containing substrates cellulose into useful biofertilizer. In the present study the substrate sugarcane bagasse taken as carbon source is bio-converted with species of earthworm Eudrilus eugeniae. The role of moisture content in the process is studied by varying moisture content from $45 \pm 5 \%, 55 \pm 5 \%, 65 \pm 5 \%$, $75 \pm 5 \%$ to $85 \pm 5 \%$. It is observed that the moisture content $75 \pm 5 \%$ is the optimal at which the vermicomposting is fastest. Other relative parameters observed varied with maximum changes in range of $75 \pm 5 \%$ of moisture content. The maximum kinetic reaction rate is recorded at the same level of moisture content.
\end{abstract}

Keywords: Cellulose, bagasse, Eudrilus eugeniae, Absolute BOD, C/N

\section{Introduction}

Worms not only reduce organic matter but also stabilize organic matter and mineralize different elements present in substrate. Mineral rich organic manure in form of compost or vermicompost can be a good replacement to chemical fertilizer. Both ways of conversion of organic waste into useful manure is not difficult but need some awareness and technical knowledge to hold control over the process of bioconversion. Besides recycling and agricultural value, tissues of worms have tremendous medicinal value in China, Japan, Malaysia, and Myanmar, including India [34, 40 \& 50]. Earthworms are mainly classified as epigic i.e. shallow burrowing [27 \& 49], aneciques i.e. deep burrowing [5] and endoges i.e. surface dwellers [1, 4, 10, 16, 27, 29 \& 39]. 


\section{Review of literature}

In many countries scientist and engineers have developed the technique to stabilize and manage generated solidwaste by communities in cities. Few processes include the Beccari Process of Italy, Boardas Process, Earp Thamos Process, Freser Process, Hardi Process and others of Europe, the Deno Process developed in Denmark and the Vam Process used in Holland etc. [8]. The first modern development of composting technique can be traced to the work of Howard in the early part of 20th century. Work on these lines was initiated as early as 1920 by the collaborative efforts of Jackson and Wad and others. But are not much fruit full, because they fail to patch nutritive demand of plant life. Indirectly it proved a device to reduce pollution potential up to certain limit. On the other hand vermicomposting is a process which reduces the pollution potential together with fulfilling the nutritive demand of plant for better yield. Presence of worm-cast in agriculture field not only enhances the fertility of land but also increase the water holding capacity of agriculture land. Full knowledge of earthworm species and its behavior corresponding to environmental parameters must be well known before the application to a specific substrate. The gut of earthworm itself works as bioreactor, where the fragmentation and grinding of substrate, bioconversion of substrate and mineralization of different elements present in substrate takes place. This is termed as vermicompost with rich nutritive value. The excreted material from $[5,12,28,34,44 \&$ 45] earthworm is highly soluble in water and is easily accepted by plant for their healthy growth. In the whole process presence of moisture content play important role in the fragmentation, the bioconversion and the mineralization. Mobility of worms also depends on moisture content [34]. The marking of optimal moisture content for earthworm is very important to get faster, economical and eco-friendly results. Many earthworm species are suitable for organic solid waste disposal. In the present study exotic species of earthworm Eudrilus eugeniae community known as "African Night Crawler" was used. This species is reported to be fast growing; ferocious eater of organic food and does not need much soil as substratum. The optimal temperature tolerance ranges from $8{ }^{\circ} \mathrm{C}$ to $30{ }^{\circ} \mathrm{C}$ for best results [15]. After the cocoons of earthworm were deposited, hatching of worms at $25^{\circ} \mathrm{C}$ occurs for three weeks and then due to availability of abundant food and space, they grow to a maximum weight of $2.5 \mathrm{~g}$ in 8 to 10 weeks thereafter most of them decline in size and slowly attain mortality at the age of 12 weeks. Only $35 \%$ to $45 \%$ of the individual survive up to 17 th week [5, 7, $14,16,17,27,31 \& 34]$. Various studies show that endoges species i.e. surface dweller earthworm are most competent than others. The earthworms have $75 \%$ to $90 \%$ water of their body weight [21]. This indicates that the whole enzymatic reactions are mainly based on moisture content. Optimal level of moisture content is essentially required for vermicomposting (survival of warms and optimal biological activity)as well as for microbial flora present in process [22]. Under adverse dry conditions of soil the worms release large amount of water from their bodies for their survival, and activity of worms get reduced [17].

\section{Materials and methods}

For experimental study the authors selected six spherical earthen pots (generally used to store drinking water in India) of about $50 \mathrm{~cm}$ diameter in middle and open mouth of about $25 \mathrm{~cm}$ diameter. With the help of power drill, twelve bores of $8 \mathrm{~mm}$ diameter 
were drilled below neck of earthen pot at $20 \mathrm{~cm}$ slant depth from the neck. Each bore was made approximately at 30 degree angle. Oval shape pebbles (collected from river bed) $10 \mathrm{~mm}$ to $25 \mathrm{~mm}$ in size were laid at the bottom of earthen pot to create $5 \mathrm{~cm}$ height. Stabilized slurry of cow dung from biogas plant was taken and mixed with agriculture soil in the ratio of. 1:1 and put over the stone bed to fill the voids and to prepare a uniform bed (substratum or plate form). Sugarcane bagasse as substrate and agriculture soil are taken and dried in oven at $550{ }^{\circ} \mathrm{C}$ and $650{ }^{\circ} \mathrm{C}$ respectively for 24 hours to expel out moisture from both. After 24 hours the both were taken out from oven and mixed in the ratio of 64\%:36\% by weight. This mixture was weighed in six lots of $14 \mathrm{~kg}$ and placed in each earthen pot. A level strip was stuck over each pot and marked as control lot, experimental lot, moisture content level, date of experiment, weight of substrate used, weight of earthworm loading, interval and days of sample collection. Record of progress in each pot was thus maintained. Out of the six pots, No 1 marked as control has moisture content maintained at $75 \pm 5 \%$ without earthworm. In the pot No 2 to pot No 6 the moisture content level is maintained at $45 \pm 5 \%, 55 \pm 5$ $\%, 65 \pm 5 \%, 75 \pm 5 \%$ and $85 \pm 5 \%$ respectively with a level difference of $10 \%$ approximately in each. This level of moisture content was checked, time to time and whenever it was observed that the moisture content level reduced in any pot the moisture content level was immediately patched by sprinkle of appropriate amount of water to recover moisture lost. True representative sample from each pot was drawn periodically and estimated for selected parameters. The Eudrilus eugeniae species of earthworm weighing $150 \mathrm{~g}$ was introduced in each experimental pot and cotton cloth net was used to cover open mouth and tied at neck of each pot to protect from fly nuisance. Earthworms were kept for 2 to 3 weeks in same composition of substrate for acclimatization. The estimation of moisture content was done with the help of quick moisture meter, cellulose by Updegraph Method (1966), Organic Carbon by Dichromate Method, Total Nitrogen by K-Jeldahal Method respectively. BOD of solid waste was measured with a slight modification in the methodology. $5 \mathrm{~g}$ of substrate sample was taken and crushed up to the colloidal particulate size with the help of mechanical device. $1 \mathrm{~g}$ by dry weight of this sample was taken and mixed with 1 liter of distilled water of known BOD in volumetric flask and the BOD at 200C of solution was estimated by dilution technique. Wherever needed mathematical calculation were done to get the result. The BOD obtained is expressed in (\%) percentage. Absolute BOD at any instance of experiment was determined with respect to dry weight of substance at that particular stage and finally this absolute BOD was used to determine $\mathrm{Kr}$ (Reaction rate) values by plotting graph between Log Lt/Lo against time in days.

\section{Results}

\section{Cellulose reduction}

The observed results of experiment are presented in Table 1 to Table 6 . The initial cellulose level in control lot was $440.20 \mathrm{mg} / \mathrm{g}$ which reduced to $385.89 \mathrm{mg} / \mathrm{g}$ which shows a poor decrease in cellulose content of total $12.34 \%$ in 48 days. While in experimental lots the gradual increase in percentage cellulose reduction was observed with increase in moisture content. The maximum reduction in cellulose content was observed at $75 \pm 5 \%$ moisture content which was initially $440.80 \mathrm{mg} / \mathrm{g}$ reaching a level of $32.8 \mathrm{mg} / \mathrm{g}$ on $48 \mathrm{th}$ day of experimentation. The decrease of cellulose by $92.56 \%$ is maximum among all the moisture content levels, the next lower reduction in 48 days 
was observed in $85 \pm 5 \%$ followed by that in $65 \pm 5 \%$ moisture content in experimental lot. This is a clear indication that after a level of $75 \pm 5 \%$ with increase or decrease in moisture content the cellulose reduction get affected.

\section{C/N reduction}

The $\mathrm{C} / \mathrm{N}$ ratio initially was 58.118 in control lot and at the end of experiment reached to a level of 51.068. It shows a poor reduction in $\mathrm{C} / \mathrm{N}$ ratio i.e. $12.13 \%$ while in Table 2 i.e. for $45 \pm 5 \%$ experimental lot better reduction of $\mathrm{C} / \mathrm{N}$ ratio i.e. $58.07 \%$ was observed. Similarly Table 3, 4, 5 shows gradual increase in $\mathrm{C} / \mathrm{N}$ ratio reduction i.e. 59.91\%, 63.85 $\%, 66.10 \%$ respectively. Table No 6 i.e. $85 \pm 5 \%$ moisture content level indicates poor reduction in $\mathrm{C} / \mathrm{N}$ ratio and reduction of $64.09 \%$ nearly equal to the $65 \pm 5 \%$ moisture content level. It is clear that $\mathrm{C} / \mathrm{N}$ ratio reaches below 20 in $75 \pm 5 \%$ moisture content of experimental lot only.

\section{Dry weight reduction}

Dry weight reduction of substrate bagasse was recorded. Increased moisture content in experimental lot from $45 \pm 5 \%$ to $75 \pm 5 \%$ showed increased reduction in dry weight from $22.9 \%, 24.9 \%, 25.32 \%$ and $28.57 \%$ respectively. Poor percentage reduction in dry weight was recorded in control (13.69\%). The percentage dry weight reduction shows a declining trend as moisture content level reaches higher range of $85 \pm 5 \%$. In this percentage reduction of dry weight was nearly $2 \%$ lower than percentage reduction in lot No. 5 i.e. of moisture content level $75 \pm 5 \%$.

\section{Absolute BOD reduction}

Comparative higher reduction in Absolute BOD values were recorded in lot No 5 at $75 \pm 5 \%$ moisture content. The maximum percentage reduction in Absolute BOD was observed to be $78.15 \%$ in lot No. 5, while $71.63 \%, 72.81 \%, 74.53 \%$ and $75.73 \%$ Absolute BOD reduction were recorded in lot No 2, 3, 4 and 6 respectively. This parameter also shows about $2 \%$ variation in each successive lot. A poor reduction in $\%$ Absolute BOD was recorded in control lot whose moisture content level was similar to experimental lot No. 5 showing greater reduction.

\section{Kinetic reaction rate and weight of earthworms}

Kinetic reaction rate of all experimental lots were compared. It was observed that the maximum reaction rate was recorded in lot No. 5 i.e. 0.013, while in control lot No. 1 it was recorded as 0.0001 which is lowest amongst the lots. The kinetic reaction rate shows the gradual increment as moisture content level increases in experimental lots from 2 to 4 i.e. $0.011,0.0114,0.012$ respectively and attained a maximum in lot No. 5 i.e. 0.013 . It is reduced in lot No. 6 i.e. 0.012 which shows a decline phase in reaction rate at higher moisture content level i.e. $85 \pm 5 \%$. At the completion of experiment weight of earthworms of each experimental lot were recorded. Recorded weight was higher than in the beginning. The weight of earthworms gets increased by $14 \%, 20 \%$, $24.7 \%, 48 \%$ and 34\% respectively in lot No. 2 to 6 respectively. This promises that the maximum bioconversion happened in lot No 5 whose moisture content level was $75 \pm 5$ $\%$. 
Table 1. Observation on bioconversion of bagasse substrate by Eudrilus eugeniae earthworm species (Control lot)

\begin{tabular}{c|c|c|c|c|c}
\hline $\begin{array}{c}\text { Time } \\
\text { days }\end{array}$ & $\begin{array}{c}\text { Cellulose } \\
\mathbf{m g} / \mathbf{g}\end{array}$ & $\begin{array}{c}\mathbf{C} / \mathbf{N} \\
\text { ratio }\end{array}$ & $\begin{array}{c}\text { Dry Weight } \\
\mathbf{k g}\end{array}$ & $\begin{array}{c}\text { BOD } \\
\mathbf{\%}\end{array}$ & $\begin{array}{c}\text { Absolute BOD } \\
\mathbf{k g}\end{array}$ \\
\hline 0.00 & 440.20 & 58.12 & 14.00 & 38.20 & 5.35 \\
4.00 & 438.60 & 57.66 & 13.95 & 38.13 & 5.32 \\
8.00 & 434.90 & 57.12 & 13.89 & 38.08 & 5.29 \\
12.00 & 431.80 & 56.68 & 13.78 & 38.01 & 5.24 \\
16.00 & 427.80 & 56.19 & 13.56 & 37.94 & 5.15 \\
20.00 & 422.40 & 55.67 & 13.42 & 37.88 & 5.08 \\
24.00 & 417.80 & 55.13 & 13.29 & 37.76 & 5.02 \\
28.00 & 412.60 & 54.54 & 13.19 & 37.65 & 4.97 \\
32.00 & 407.30 & 54.08 & 13.09 & 37.55 & 4.92 \\
36.00 & 402.00 & 53.66 & 12.99 & 37.43 & 4.86 \\
40.00 & 397.30 & 53.01 & 12.90 & 37.32 & 4.82 \\
44.00 & 391.80 & 52.10 & 12.89 & 37.21 & 4.80 \\
48.00 & 385.90 & 51.07 & 12.80 & 37.06 & 4.74 \\
\hline
\end{tabular}

* $\quad$ Moisture Content level kept $75 \pm 5 \%$ through experiment period. (Control lot)

** Agriculture Soil 36\% + Sugarcane Bagasse Substrate $64 \%$ by weight

*** Earthworm weight Eudrilus eugeniae initial weight $0 \mathrm{gm}$ at the beginning of experiment

**** Earthworm weight Eudrilus eugeniae final weight $0 \mathrm{gm}$ at the end of experiment i.e. 00\% increase in weight

Table 2. Observation on bioconversion of bagasse substrate by Eudrilus eugeniae earthworm species ( $M C 45 \pm 5 \%$ experiment lot)

\begin{tabular}{c|c|c|c|c|c}
\hline $\begin{array}{c}\text { Time } \\
\text { days }\end{array}$ & $\begin{array}{c}\text { Cellulose } \\
\mathbf{m g} / \mathbf{g}\end{array}$ & $\begin{array}{c}\mathbf{C} / \mathbf{N} \\
\text { ratio }\end{array}$ & $\begin{array}{c}\text { Dry Weight } \\
\mathbf{k g}\end{array}$ & $\begin{array}{c}\text { BOD } \\
\mathbf{\%}\end{array}$ & $\begin{array}{c}\text { Absolute BOD } \\
\mathbf{k g}\end{array}$ \\
\hline 0.00 & 438.90 & 56.94 & 14.00 & 38.82 & 5.43 \\
4.00 & 430.30 & 56.14 & 13.97 & 38.71 & 5.41 \\
8.00 & 420.50 & 53.58 & 13.85 & 37.46 & 5.19 \\
12.00 & 406.00 & 50.63 & 13.66 & 35.71 & 4.88 \\
16.00 & 397.20 & 47.22 & 13.26 & 33.39 & 4.43 \\
20.00 & 386.20 & 43.43 & 13.02 & 30.67 & 3.99 \\
24.00 & 365.20 & 37.96 & 12.68 & 26.40 & 3.35 \\
28.00 & 338.80 & 34.27 & 12.21 & 21.35 & 2.61 \\
32.00 & 297.20 & 31.41 & 11.84 & 18.28 & 2.17 \\
36.00 & 248.30 & 29.04 & 11.55 & 16.38 & 1.89 \\
40.00 & 158.30 & 26.69 & 11.16 & 15.53 & 1.73 \\
44.00 & 109.70 & 24.44 & 10.81 & 14.64 & 1.58 \\
48.00 & 78.60 & 22.83 & 10.51 & 14.05 & 1.48 \\
\hline
\end{tabular}

* $\quad$ Moisture Content level kept $45 \pm 5 \%$ through experiment period (Experimental lot)

** Agriculture Soil 36\% + Sugarcane Bagasse Substrate $64 \%$ by weight

*** Earthworm weight Eudrilus eugeniae initial weight $150 \mathrm{gm}$ at the beginning of experiment

**** Earthworm weight Eudrilus eugeniae final weight $171 \mathrm{gm}$ at the end of experiment i.e. $14 \%$ increase in weight 
Table 3. Observation on bioconversion of bagasse substrate by Eudrilus eugeniae earthworm species ( $M C 55 \pm 5 \%$ experiment lot)

\begin{tabular}{c|c|c|c|c|c}
\hline $\begin{array}{c}\text { Time } \\
\text { days }\end{array}$ & $\begin{array}{c}\text { Cellulose } \\
\mathbf{m g} / \mathbf{g}\end{array}$ & $\begin{array}{c}\mathbf{C} / \mathbf{N} \\
\text { ratio }\end{array}$ & $\begin{array}{c}\text { Dry Weight } \\
\mathbf{k g}\end{array}$ & $\begin{array}{c}\text { BOD } \\
\text { \% }\end{array}$ & $\begin{array}{c}\text { Absolute BOD } \\
\text { kg }\end{array}$ \\
\hline 0.00 & 438.90 & 56.94 & 14.00 & 38.82 & 5.43 \\
4.00 & 430.30 & 56.14 & 13.97 & 38.71 & 5.41 \\
8.00 & 420.50 & 53.58 & 13.85 & 37.46 & 5.19 \\
12.00 & 406.00 & 50.63 & 13.66 & 35.71 & 4.88 \\
16.00 & 397.20 & 47.22 & 13.26 & 33.39 & 4.43 \\
20.00 & 386.20 & 43.43 & 13.02 & 30.67 & 3.99 \\
24.00 & 365.20 & 37.96 & 12.68 & 26.40 & 3.35 \\
28.00 & 338.80 & 34.27 & 12.21 & 21.35 & 2.61 \\
32.00 & 297.20 & 31.41 & 11.84 & 18.28 & 2.17 \\
36.00 & 248.30 & 29.04 & 11.55 & 16.38 & 1.89 \\
40.00 & 158.30 & 26.69 & 11.16 & 15.53 & 1.73 \\
44.00 & 109.70 & 24.44 & 10.81 & 14.64 & 1.58 \\
48.00 & 78.60 & 22.83 & 10.51 & 14.05 & 1.48 \\
\hline
\end{tabular}

* $\quad$ Moisture Content level kept $55 \pm 5 \%$ through experiment period (Experimental lot)

** Agriculture Soil 36\% + Sugarcane Bagasse Substrate $64 \%$ by weight

*** Earthworm weight Eudrilus eugeniae initial weight $150 \mathrm{gm}$ at the beginning of experiment

**** Earthworm weight Eudrilus eugeniae final weight $180 \mathrm{gm}$ at the end of experiment i.e. 20\% increase in weight

Table 4. Observation on bioconversion of bagasse substrate by Eudrilus eugeniae earthworm species ( $M C 65 \pm 5 \%$ experiment lot)

\begin{tabular}{c|c|c|c|c|c}
\hline $\begin{array}{c}\text { Time } \\
\text { days }\end{array}$ & $\begin{array}{c}\text { Cellulose } \\
\mathbf{m g} / \mathbf{g}\end{array}$ & $\begin{array}{c}\mathbf{C} / \mathbf{N} \\
\text { ratio }\end{array}$ & $\begin{array}{c}\text { Dry Weight } \\
\mathbf{k g}\end{array}$ & $\begin{array}{c}\text { BOD } \\
\mathbf{\%}\end{array}$ & $\begin{array}{c}\text { Absolute BOD } \\
\mathbf{k g}\end{array}$ \\
\hline 0.00 & 442.80 & 57.03 & 14.00 & 38.85 & 5.44 \\
4.00 & 434.00 & 56.21 & 13.97 & 38.73 & 5.41 \\
8.00 & 420.70 & 53.54 & 13.83 & 37.37 & 5.17 \\
12.00 & 407.60 & 50.32 & 13.64 & 35.55 & 4.85 \\
16.00 & 396.30 & 46.65 & 13.19 & 33.02 & 4.36 \\
20.00 & 385.30 & 42.43 & 12.19 & 29.91 & 3.85 \\
24.00 & 363.30 & 36.80 & 12.57 & 24.86 & 3.13 \\
28.00 & 335.20 & 32.12 & 12.17 & 20.09 & 2.44 \\
32.00 & 291.00 & 29.28 & 11.75 & 17.52 & 2.06 \\
36.00 & 239.10 & 26.84 & 11.34 & 15.62 & 1.77 \\
40.00 & 141.70 & 24.45 & 10.97 & 15.15 & 1.66 \\
44.00 & 88.60 & 22.22 & 10.51 & 13.86 & 1.46 \\
48.00 & 62.10 & 20.62 & 10.46 & 13.25 & 1.39 \\
\hline
\end{tabular}

* $\quad$ Moisture Content level kept $65 \pm 5 \%$ through experiment period (Experimental lot)

** Agriculture Soil 36\% + Sugarcane Bagasse Substrate $64 \%$ by weight

*** Earthworm weight Eudrilus eugeniae initial weight $150 \mathrm{gm}$ at the beginning of experiment

**** Earthworm weight Eudrilus eugeniae final weight $196 \mathrm{gm}$ at the end of experiment i.e. $23.47 \%$ increase in weight 
Table 5. Observation on bioconversion of bagasse substrate by Eudrilus eugeniae earthworm species (M C $75 \pm 5 \%$ experiment lot)

\begin{tabular}{c|c|c|c|c|c}
\hline $\begin{array}{c}\text { Time } \\
\text { days }\end{array}$ & $\begin{array}{c}\text { Cellulose } \\
\mathbf{m g} / \mathbf{g}\end{array}$ & $\begin{array}{c}\mathbf{C} / \mathbf{N} \\
\text { ratio }\end{array}$ & $\begin{array}{c}\text { Dry Weight } \\
\mathbf{k g}\end{array}$ & $\begin{array}{c}\text { BOD } \\
\mathbf{\%}\end{array}$ & $\begin{array}{c}\text { Absolute BOD } \\
\text { kg }\end{array}$ \\
\hline 0.00 & 440.80 & 57.18 & 14.00 & 38.90 & 5.45 \\
4.00 & 431.60 & 56.25 & 13.97 & 38.76 & 5.41 \\
8.00 & 418.40 & 53.30 & 13.82 & 37.30 & 5.16 \\
12.00 & 404.90 & 49.80 & 13.60 & 35.10 & 4.77 \\
16.00 & 390.60 & 45.10 & 13.14 & 32.30 & 4.32 \\
20.00 & 374.30 & 40.00 & 12.80 & 28.42 & 4.64 \\
24.00 & 354.20 & 34.32 & 12.38 & 23.19 & 2.87 \\
28.00 & 319.00 & 28.50 & 11.91 & 18.03 & 2.14 \\
32.00 & 256.80 & 25.60 & 11.46 & 15.86 & 1.82 \\
36.00 & 194.60 & 23.19 & 10.96 & 14.02 & 1.54 \\
40.00 & 124.40 & 21.39 & 10.50 & 13.13 & 1.38 \\
44.00 & 52.60 & 20.35 & 10.03 & 12.15 & 1.22 \\
48.00 & 32.80 & 19.38 & 10.00 & 11.90 & 1.19 \\
\hline
\end{tabular}

* $\quad$ Moisture Content level kept $75 \pm 5 \%$ through experiment period (Experimental lot)

** Agriculture Soil 36\% + Sugarcane Bagasse Substrate $64 \%$ by weight

*** Earthworm weight Eudrilus eugeniae initial weight $150 \mathrm{gm}$ at the beginning of experiment

**** Earthworm weight Eudrilus eugeniae final weight $222 \mathrm{gm}$ at the end of experiment i.e. $48 \%$ increase in weight

Table 6. Observation on bioconversion of bagasse substrate by Eudrilus eugeniae earthworm species (M C $85 \pm 5 \%$ experiment lot)

\begin{tabular}{c|c|c|c|c|c}
\hline $\begin{array}{c}\text { Time } \\
\text { days }\end{array}$ & $\begin{array}{c}\text { Cellulose } \\
\mathbf{m g} / \mathbf{g}\end{array}$ & $\begin{array}{c}\mathbf{C} / \mathbf{N} \\
\text { Ratio }\end{array}$ & $\begin{array}{c}\text { Dry Weight } \\
\text { kg }\end{array}$ & $\begin{array}{c}\text { BOD } \\
\text { \% }\end{array}$ & $\begin{array}{c}\text { Absolute BOD } \\
\text { kg }\end{array}$ \\
\hline 0.00 & 438.60 & 57.02 & 14.00 & 38.68 & 5.42 \\
4.00 & 429.90 & 56.17 & 13.97 & 38.55 & 5.39 \\
8.00 & 416.90 & 53.46 & 13.83 & 37.13 & 5.14 \\
12.00 & 404.20 & 50.02 & 13.62 & 35.20 & 4.79 \\
16.00 & 392.60 & 45.83 & 13.16 & 32.66 & 4.30 \\
20.00 & 380.70 & 41.37 & 12.83 & 29.40 & 3.77 \\
24.00 & 357.50 & 36.04 & 12.46 & 23.95 & 2.98 \\
28.00 & 329.00 & 30.86 & 12.04 & 18.98 & 2.29 \\
32.00 & 285.10 & 27.47 & 11.59 & 16.67 & 1.39 \\
36.00 & 228.10 & 25.57 & 11.20 & 15.47 & 1.73 \\
40.00 & 120.40 & 22.88 & 10.78 & 14.70 & 1.59 \\
44.00 & 70.20 & 21.33 & 10.33 & 13.19 & 1.36 \\
48.00 & 57.00 & 20.47 & 10.27 & 12.80 & 1.31 \\
\hline
\end{tabular}

* $\quad$ Moisture Content level kept $85 \pm 5 \%$ through experiment period (Experimental lot)

** Agriculture Soil $36 \%+$ Sugarcane Bagasse Substrate $64 \%$ by weight

*** Earthworm weight Eudrilus eugeniae initial weight $150 \mathrm{gm}$ at the beginning of experiment

**** Earthworm weight Eudrilus eugeniae final weight $201 \mathrm{gm}$ at the end of experiment i.e. 34\% increase in weight 


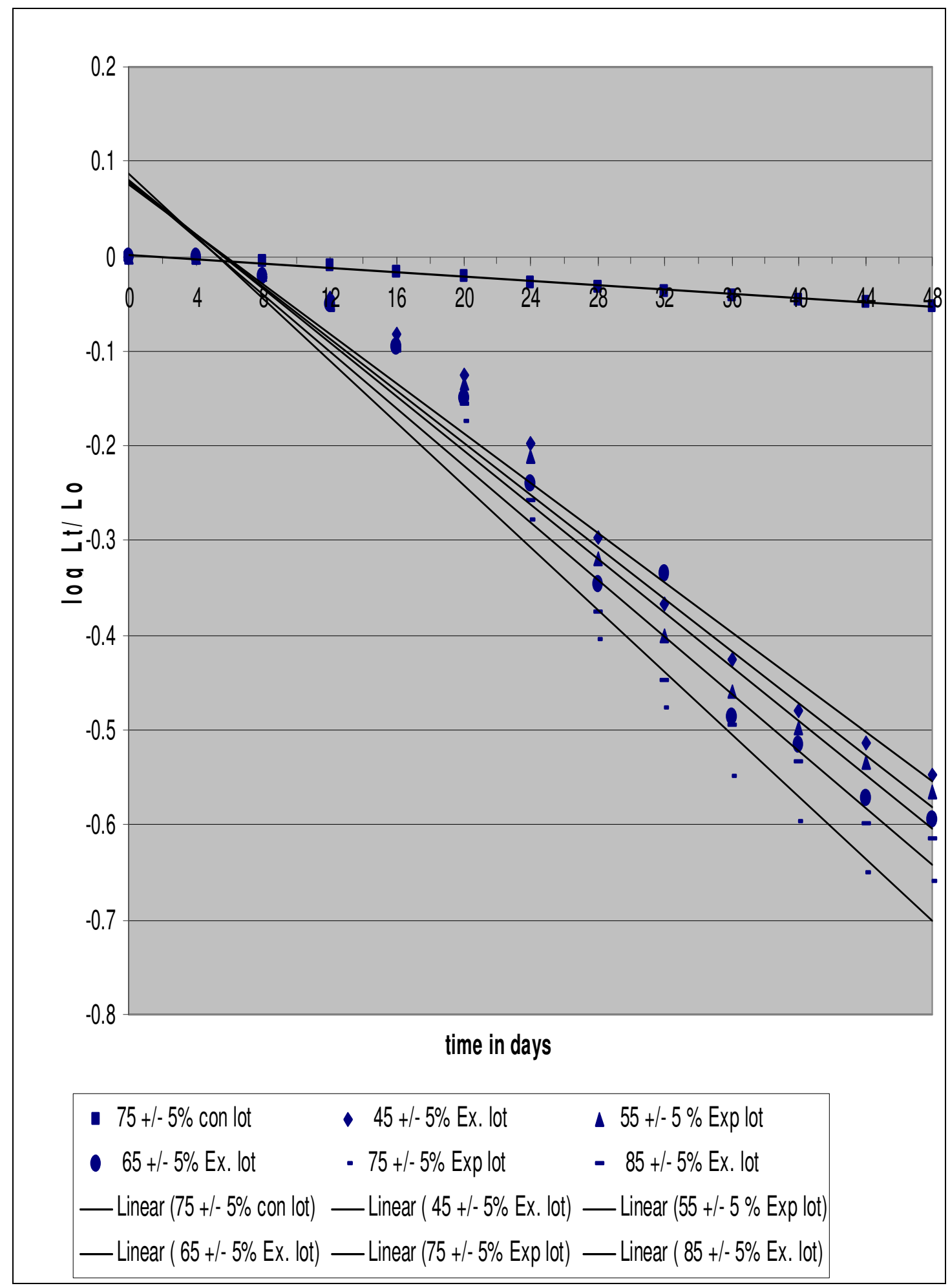

Figure 1. Reaction rate 


\section{Discussion}

Vermicomposting has become increasingly popular in the last two decades as an alternative to incineration of decomposable organic waste. In the whole process typical biochemical reactions involve were based on the path of bioconversion selected. In the current study the specie of earthworm Eudrilus eugeniae and variation in moisture content highly influenced the bioconversion process as displayed in table No. 2 to 6 . Increased level of moisture content from $45 \pm 5 \%$ to $75 \pm 5 \%$ increases bioconversion and as the level reaches $85 \pm 5 \%$ bioconversion decreases. The present study points out that whenever moisture content level exceeds to $75 \pm 5 \%$ adverse effect are produced over bioconversion rate probably due to the replacement of existing voids of air by water which also results in emission of pungent odour [2] Further the water can also exert suction representing a negative pressure and the moisture retention can be termed as matric potential [23]. However in present study the matric potential has not been measured.

In cellulosic material i.e. sugarcane bagasse holds water in the cell wall which is dried at beginning of experiment. Present authors agree with Miller [35 \& 36] that there is generation of high amount of metabolic water by hydrolysis of polysaccharides contributing to the total moisture content. Cellulose is a problematic organic waste which impedes the biodegradation process. Cellulose breakdown calls for a prolonged pretreatment as it contains several components like cellulose, hemicellulose, lignocelluloses, lignin, protein and fats. Authors agree with statement of Kyriaeou et.al [33] that during bioconversion enzyme complex secreted by microbial agencies present in experiment system, also causes the cellulose fragmentation activity. Kurakake et.al. [32] removed $76 \%$ of lignin by pretreatment of bagasse waste by cyclohexanol mixture. While Raul et. al. [38] did not give any degree of treatment to bagasse before their bioconversion study and measured Total Nitrogen, Cellulose, Hemicellulose, Lignin and Ash Content, Kurakake et.al [32] suggested that enzymatic hydrolysis process pretreatment causes hydrophobic degradation. In the present study no pretreatment technology was used. Only substrate bagasse and agriculture soil were dried in oven to remove the moisture held in both to help dry the cell wall of microorganisms present in soil. Vermicomposting is a mixed adventure caused by microorganisms and earthworms. To determine reaction rate at initial stage, soil and substrate were dried for natural growth of microflora and to estimate real reaction rate from beginning of experiment. Although the interactions between microorganisms and earthworms have received a considerable attention [6], the role of microorganism in gut transit is still controversial [51], even though it is proved now that the bacteria and fungi are digested by earthworms [18, $24 \&$ 48]. During vermicomposting Doube and Brown [13] concluded that earthworm have minimum capacity to digest the cellulose containing organic residue and obtained their food nutrition by digestion of microbial flora, associated with ingested organic matter, which is only possible at optimum moisture content level.

\section{Cellulose reduction}

In the present study of bagasse vermicomposting maximum percentage cellulose consumption was noticed at $75 \pm 5 \%$ moisture content level. It indicates that optimal biological activity takes place to degrade and stabilize the cellulose present in bagasse substrate with high metabolic biological reaction, hydrolysis and fragmentation 
occurring at certain level of moisture (Table 5). In the study of bioconversion, during composting of domestic refuse Kapetonios et.al. [30] recorded a faster degradation of cellulose than lignin. Godder and Peninck [20] recorded only $21.2 \%$ cellulose reduction after 50 days of their experimentation and Kapteonios et.al. [30] have reported up to 53 $\%$ reduction of cellulose. Present authors recorded higher percentage cellulose reduction at lower duration compare to others.

\section{C/N reduction}

$\mathrm{C} / \mathrm{N}$ ratio is one of the most widely used parameter to monitor the progress of bioconversion. Much importance was given to this parameter by Raul et.al. [38], Flintoff [19], Tchobanoglous et.al. [47], Ambrose [2] and others. Sunderrajan et.al. [46] in their study during anaerobic digestion of kitchen waste did not consider $\mathrm{C} / \mathrm{N}$ as a significant parameter to measure process, but chose COD and volatile solids to monitor the process development. Chanyasak and Kubota [11], recommended ratio of Carbon/Organic Nitrogen comparatively more dependable than $\mathrm{C} / \mathrm{N}$ ratio and suggested non dependability of $\mathrm{C} / \mathrm{N}$ ratio in solid waste composting as indicator of composting maturity and concluded that it can not be used as an absolute indicator of compost maturity. But question rises for its importance in bioconversion probably due to interchanging pattern of carbon released by carbohydrate degradation and established ammonification process, making both carbon and nitrogen highly fluctuating. The authors agree with Carvalho et.al. [9] contention, that $\mathrm{C} / \mathrm{N}$ ratio is undependable due to its lack of control on entire vermicomposting process. Due to this reason authors laid more trust on percentage BOD and Absolute BOD as they are more dependable. Beside these authors suggested new dependable monitoring parameter like reaction rate $(\mathrm{Kr})$ values to monitor the rate of vermicomposting reaction. Raul et.al. [38] recommended the optimum $\mathrm{C} / \mathrm{N}$ ratio range from 30 to 50; Flintoff [19] advised that the suitable ratio may range from 20 to 70 depending on available carbon. The authors suggest that if the $\mathrm{C} / \mathrm{N}$ ratio is kept up to 60 at initial stage of experiment, it will promote bioconversion process and will not exert any disorder during vermicomposting. In the present study the initial $\mathrm{C} / \mathrm{N}$ ratio kept as 57.18 reached 19.38 by the 48th day of experimentation, indicating the near completion of vermicomposting process. Ashbolt and Line [3] have also reported a strong Nitrogen relationship to $\mathrm{C} / \mathrm{N}$ ratio which supports authors work.

The Biochemical Oxygen Demand BOD values are often recorded in river, pond, stream, effluent and sewage etc. This indicative parameter shows the pollution level and is generally referred to BOD5 values from landfill leaches but fails to estimate reaction rate of biodegradation. As per authors suggestion the estimation of BOD value is essential for computing reaction rate. The earlier authors did not estimate BOD values as essential parameter, probably due to long procedure involved in determination. Much more attention is required to establish reaction rate $(\mathrm{Kr})$ as a indicative parameter to hold safe and more control over the whole vermicomposting process.

\section{Conclusion}

Vermicomposting is a mixed adventure of mixed microbes and earthworms. From previous experiments [37, 41, $42 \& 43$ ] we gather maximum activities of various microbial and earthworm species at best suited optimum level of moisture content. A constant monitoring and hold on progress of the process is thus required. In the present study bioconversion is also influenced by maturity of substrate due to presence of 
varying concentration of cellulose, hemicellulose, lignocelluloses, lignin etc. Introduction of specific microbial species synthesizing set of cellulase enzymes hastens the process of vermicomposting.

Enzymatic degradation proceeding as exothermal reaction retards the activity of earthworm beyond limit of their thermal tolerance. This may sweep of earthworm population from vermicompost thus causing reduction of fixed nitrogen and potassium level. It is therefore essential that use of specific inoculum for rapid degradation and higher nutritive values demand for control of liberated heat. Further experimental studies are required to establish final reaction rate and fix desired concentration of essential elements for healthy plant growth.

Acknowledgements. Authors are highly thankful to Dr. K.S. Rao Ex-professor \& Head of Environmental Division School of Studies in Zoology Vikram University Ujjain, for his advice and possible facilities required to complete this experimental work to conclude out the result also authors thanks to all those who helped them directly or indirectly to reach over this stage of presentation for this experimental work.

\section{REFERENCES}

[1] Albanell, E., Plaixats, J. and Cabrero, T. (1988): Chemical changes during vermicomposting ( $E$ fetida) of sheep manure mixed with cotton industries waste. Biology and Fertility of Soils 6(3): 266-269.

[2] Ambrose, J.A. (1983): Developments in the composting of refuse. - Publ. in practical waste management Ed. by Holmes, J.R. Publ. John Wiley \& Sons Ltd.

[3] Ashbolt, N.J., and Line, M.A. (1982): A banch scale system to study the compost of organic waste. - J. Environ. Qual. 11(3): 405-408.

[4] Bansal, S. and Kapoor, K.K. (2000): Vermicomposting of crop residues and cattle dung with Eisenia foetida. - Bioresource Technology 73: 95-98.

[5] Bhawalkar, U.S. (1995): Vermiculture bioconversion of organic residues. - Ph.D. Thesis, I.I.T.Mumbai, India

[6] Brown, G.G. (1995): How do earthworms effect microfloral and faunal community diversity? - Plant Soil 170: 209-231.

[7] Camp, Dresser and McKee Inc. (1980): Compendium on solid waste management by vermicomposting. - Cincinnati, OH, Municipal Environmental Research Lab, EPA.

[8] Cardenas, R.R. and Wang, L.K. (1980): Composting process - Chapter V in Hand book of Environmental Engineering Vol.2 Eds/Wang, L.K. andPareira, N.C. The Humana press. Clifton, New Jersey.

[9] Carvalho, R.A.G.de., Beca, C.G.G, Neves, O.R. and Pereira, M.C.S. (1991): Composting of píne and Eucalyptus Banks. - Bioresource Technology. 38: 51-63.

[10] Chan, P.L.S. and Grififiths, D.A. (1988): The vermicomposting of pre treated pig manures. - Biological wastes 24(1): 57-69.

[11] Chanyasak, V. and Kubota, H. (1981): Carbon/organic Nitrogen ratio in water extract as measure of composting degradation. - J. Ferment. Technol. 59(3): 215-219.

[12] Delgado, M., Digeriego, M., Walter, I. and Calbo, R. (1995): Use of California redworm in sewage sludge transformation. - Turrialba 45: 33-41.

[13] Doube, B.M. and Brown, G.G. (1998): Life in a complex community: functional interaction between earthworms, organic matter, microorganisms and plant growth. - In: C.A. Edwards (ed.). Earthworm Ecology. St. Lucic Press. Boca Raton, p. 179-211.

[14] Edward, C.A. (1995): Earthworms. - McGraw-Hill Encyclopedia, p. 81-83.

[15] Edward, C.A. and Bater, J.E. (1992): The use of earthworm in environmental management. - Soil Biol. Biochem. 24(12): 1683-1689. 
[16] Edward, C.A. and Bohlen, P.J. (1996): Biology and ecology of earthworms ( ${ }^{\text {rd }}$ ed.). Chapman and Hall, London.

[17] Edward, C.A. and Lofty, J.R. (1977): Biology of earthworms. - Chapman and Hall, London.

[18] Flack, F.M. and Hartenstein, R. (1984): Growth of the earthworm Eisenia foetida on microorganisms and cellulose. - Soil Biol. Biochem 16: 491-495.

[19] Flintoff, F. (1976): Management of solid wasíe in developing countries (IInd Ed.) - WHO Regional Publication South East Asian series no. 1, World Health Organization, New Delhi.

[20] Godder, B. and Peninck, M. (1986): Biochemistry of mature composting: lignin biotransformation and humification. - Proc. Int. symp. on compost; production , quality and use. Udine.

[21] Grant, W.C. (1955): Studies on moisture relationship in Earthworms. - Ecology 36(3): 400-407.

[22] Gray, K.R., Sherman, K. and Biddle, S.A.J. (1971): A Review of composting part I. Process Biochem. 6(10): 22-28.

[23] Griffin, D.M. (1972): Ecology of soil fungi. - Publ. Chapman and Hall, London. p. 1-135.

[24] Hand, P., Hayes, W.A., Frankland, J.C. and Satehrll, J.E. (1988): Vermicomposting of cow slurry. - Pedobiologia 31: 199-209.

[25] Howard, A. (1943): An Agriculture Testament. - Oxford university press, London.

[26] Howard, A., and Wad, Y.D. (1931): The waste products of Agriculture. - Oxford University press, London.

[27] Ismail, S.A. (1997): Vermicology the biology of earthworms. - Orient Longman Limited, Hyderabad (A.P.). India.

[28] Jambhekar. H.A. (1992): Use of Earthworms as a potential source to decompose organic waste. - Proceeding of the National Seminar on Organic Farming. Mahatama Phule Krishi Vidyapeeth, Pune, India p.52-53.

[29] Kale, R.D., Bano, K. and Krishnamoorthy, R.W. (1982): Potential of Perinoyx excavatus for utilization of organic waste. - Pedobiologia 23: 419-426.

[30] Kapetonios,E.G., Loizidou,M. and Valkanas,G. (1993): Compost production from Greek domestic refuse. Bioresource Technology 44.(1): 13-16.

[31] Kuo, B.C. (2001): Automatic control system. - Prentice Hall of India Private Limited, New Delhi, India.

[32] Kurakake, M., Ooshima, H., Kato, J. and Harano, Y. (1994): Pretreatment of bagasse nonionic surfactant for the enzymatic hydrolysis. - Bioresource Technology 49: 247-251.

[33] Kyriacou, A., Mackenzie, C.R. and Neufield, R.J. (1987): Detection and characterization of specific and non specific endoglucanases of Trichoderma ressel: evidence demonstrating endogluccnase activity by cellobiohydrolase II. - Enzyme microb. TechnoL 9(1): 25-32.

[34] Lunt, L.A. and Jacobson, G.M. (1944): The chemical composition of earthworm casts. Soil Science 58: 367.

[35] Miller, F.C. (1991): Biodegradation of solid waste by composting. - Chapter I in manual of solid waste disposal by WHO Ed. London, U.K. p. 1-29.

[36] Miller, F.C. (1993): Composting as a process based on the control of ecologically selective factors - In Meeting FB (ed) Soil Microbial Ecology. Marcel Dekker, NewYork, p. 515-544.

[37] Pacholi D., Sharma R. and Chauhan U.K. (1997): Bioconversion of organic waste by application of Aspergillus terrueus $\left(\mathrm{M}_{3}\right)$ - ICIPACT- 97 proceeding p. 666-671.

[38] Raul, J.H., Gomez, C. and Park,Y.K. (1983): Conversion of cane bagasse to .compost and its chemical characteristics. - J. Ferment, Technol. vol. 61(3): 329-332.

[39] Santamaria - Romero, S. and Ferrera-Cerrato, R. (2002): Population dynamics of Eisenia andrei (Bouche1972) in different organic waste. - Terra 20: 303-310. 
[40] Satchell, J.E. (1955): Some aspects of earthworm ecology. - In: Keven, D.K. Mc E. (ed.):Soil Zoology, Butterworths, London.

[41] Sharma D. and Chouhan U.K. (2000): Bio-management of cellolosic waste. - J. IAEM 27: 221-223.

[42] Sharma, R., Sharma, D., Rao, K. S. and Jain, R.C. (1999): Experimental studies on bioconversion efficiencies of sugarcane bagasse to compost. - Env.Poll.Manag p. 102108.

[43] Sharma, R., Sharma, D., Rao, K. S. and Jain, R.C. (2002): Environmental studies on waste paper pulp biodegradation. - J. Environ. Hlth. 44(3): 181-188.

[44] Sharma, S. and Vasudevan, P. (1999): Utilization of organic waste, through vermicomposting route, for plants growth. - In: R' 99 Congress (Recovery, Recycling, Re-integration), February.

[45] Singh, N.B., Khare, A.K., Bhargava, D.S. and Agrawal, S. (2003): Vermicomposting of tomato skin and seed waste. - Jr. Institute of Engineers (India) 84: 30-34.

[46] Sundararajan, R., Jayanthi, S. and Sadhasivan, P. (1996): Anaerobic digestion for the recovery of energy from Kitchen refuse. - Indian J. Environ. Hlth. 38(1): 7-12.

[47] Tchobanoglous, G., Theisen, H. and Vigil, S.A. (1993): Integrated solid waste management engineering principles and management issues. - McGraw Hill Bookcompany, New York. p. 1-980.

[48] Tiwari, S. C. and Mishra, R.R. (1993): Fungal abundance and diversity in earthworm casts and in uningested soil. - Biol. Fertil. Soils 16: 131-134.

[49] Tripathi, G. and Bhardwaj, P. (2004): Comparative studies on biomass production, life cycle and composting efficiency of Eisenia fetida (Savigny) and Lampito mauritii (Kinberg). - Bioresource Technology 92(3): 275-283.

[50] Wallwork, J.A. (1983): Earthworm biology. - Edward Arnold (Publishers) Ltd. London.

[51] Wolter, C. and Scheu, S. (1999): Changes in bacterial number and hyphal lengths during the gut passage through Lumbricus terrestris (Lumbricidae, Oligochacta). - Pedobiology 43: 891-900. 